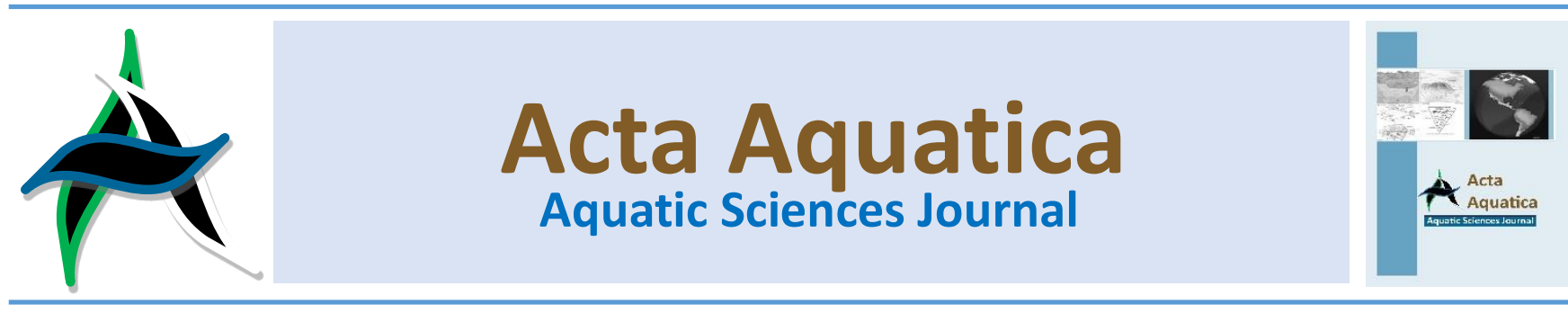

\title{
The first record of the mole crab (Albunea carabus L. 1758, Decapoda, Anomura, Hippidea) in the Gulf of Antalya
}

\author{
Mehmet Gökoğlu a, *, Serkan Teker ${ }^{a}$ and Kemal Gökoğlu \\ ${ }^{a}$ Faculty of Fisheries, Akdeniz University, Turkey \\ ${ }^{b}$ Faculty of Fisheries, Süleyman Demirel University, Turkey
}

\begin{abstract}
The first occurence of the mole crab (Albunea carabus L. 1758) in the Gulf of Antalya. During a commercial shrimp fishery oparation in May, 2016, A different type of crab was caught in the Gulf of Antalya, Bogazkent (Köprüçayı). This unknown sample was brought to Akdeniz Üniversity Fisheries Laboratory and It was stored. Sample was caught with shrimp nets that were left at depths of 10-20 m in the Gulf of Antalya, Bogazkent (Köprüçay River). It has been determined that this elongated mole, caught in the identification of the species, is Albunea carabus L. 1758, known as the dengue. Mole crab (Albunea carabus L. 1758) was reported for the first time from the Gulf of Antalya via this article.
\end{abstract}

Keywords: Albunea carabus; the Gulf of Antalya; mole crab

\section{Introduction}

Decapods in Crustacea are crabs, crayfish and shrimps which lived in freshwater and sea. Hippoidea superfamily crabs are generally known as mole crabs. This superfamily has three subfamilies. One of these subfamilies is Albuneidae and is represented with Albunea carabus L. 1758, which is known only as a mole crusher in the Mediterranean Mole crabs are very rare species because they usually live buried in the bottom. Pereira et al. (2017) reported that the researchers detected this species in 2-40 m depths.

Giacobbe and Spanò (1996) first identified the mole crab Albunea carabus in the Tyrrhenian Sea in the Messina Strait. These researchers caught four mature males and one ovigerous female in their studies. Spano et al. (1998) have caught two individuals, one female and one male during the dredge sampling in the depths of $2.5-5 \mathrm{~m}$ in Sicily Strait in 1996. Seridji (2007) has identified the larvae of this species in zoae stages during plankton samplings on the Algerian coast. This species was detected for the first time in Rhodes Island, Aegean Sea by Corsini-Foka and Kalogirou (2013) and in the Egyptian waters by Abdelsalam and Ramadan (2017).

A. carabus also distributes on the eastern Atlantic coast except of the Mediterranean (Boyko, 2002). This species which lives in sandy bottoms usually continues it life by burying itself in the bottom Preira et al. (2008) obtained this species by dredge during the bivalve sampling on the Portuguese coasts. The

\footnotetext{
* Corresponding author: Faculty of Fisheries, Akdeniz University, 07058. Antalya, Turkey. Tel: +905358554167

e-mail: gokoglu@akdeniz.edu.tr

doi: http://doi.org/10.29103/aa.v6i1.1131
}

researchers reported this example as the first record from the Portuguese coasts.

This species was the first reported from Iskenderun Bay (Turkey) in Eastern Mediterranean by Katağan and Çevik (2003). Shrimp fishing is being done by trammel nets in the front of Köprüçay of the Gulf of Antalya. During these fishing operations, a different crab species was caught by shrimp nets. The aim of this study is to identify this unknown species and to add to biodiversity of the Gulf of Antalya.

\section{Materials and methods}

Shrimp fishing is being done by trammel nets in the front of Köprüçay of the Gulf of Antalya (36 $47^{\prime} 10.98^{\prime \prime K}$; $31^{\circ}$ $\left.7^{\prime} 58.66^{\prime \prime D}\right)$. Shrimp nets were ledt to the designated coordinate zone in the sunset and were gathered in sunrise. The nets used in fishing are 210 / d, pannier webs equipped with 0 number 60 mesh with $24 \mathrm{~mm}$ mesh size. During a commercial shrimp fishery oparation in May, 2016, a different crab species was caught in the Gulf of Antalya, Bogazkent (Köprüçay River). This unknown sample was brought to the laboratory in Akdeniz University, Fisheries Faculty. In all counts, morphological features was measured. The species was identified according to Boyko (2002), Abdelsalam and Ramadan (2017). The specimen has been stored in $4 \%$ formol solution and deposited in the Museum of the Faculty of Fisheries, Akdeniz University (AU-SUF/2018-2).

\section{Result and discussion}

The The species of crab caught by shrimp nets left in the Gulf of Antalya, Köprüçay has been determined. It has been identified as mole crab, Albunea carabus (Fig 1-2). The 
morphological features of this crab were similar to features reported by Boyko (2002), Abdelsalam and Ramadan (2017). via this study. One more species has been added to biodiversity of the Gulf of Antalya via this study.

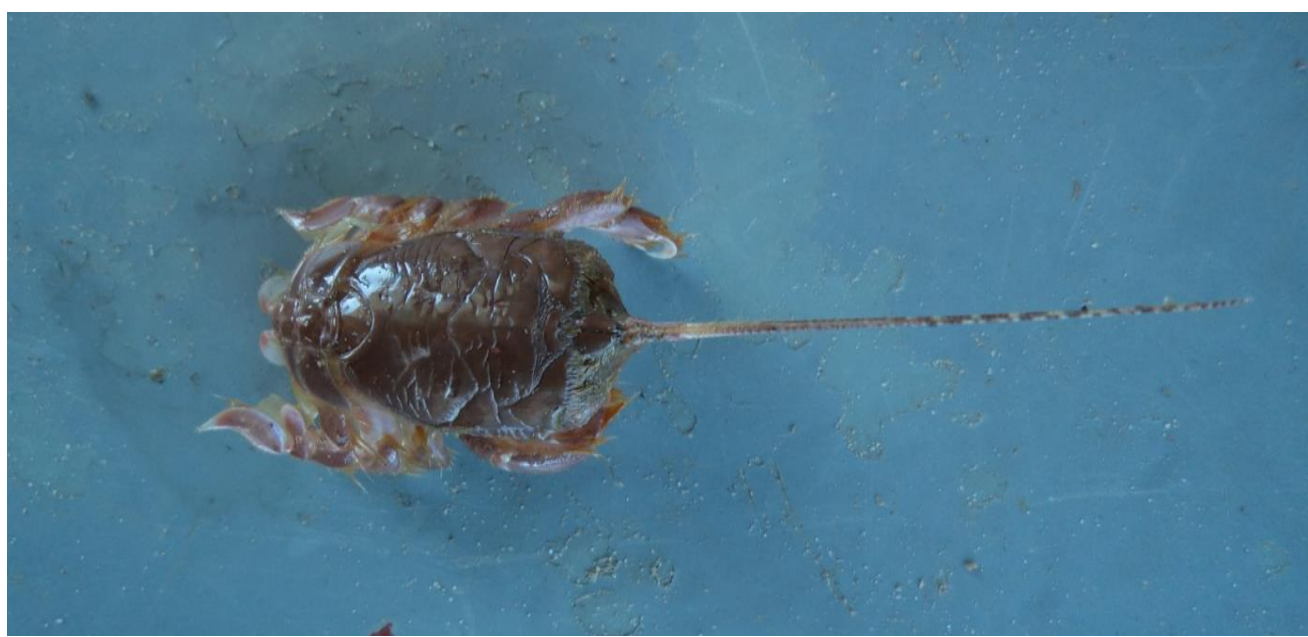

Figure 1. Dorsal view of mole crab (Albunea carabus L. 1758)

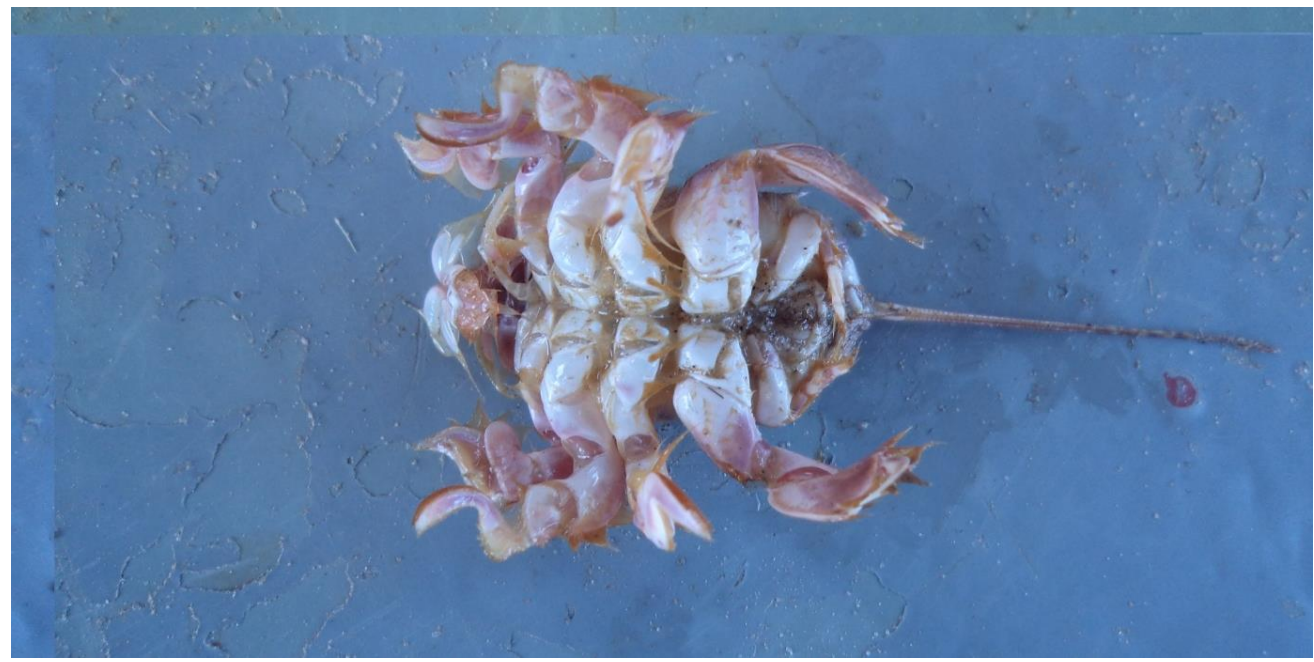

Figure 2. Abdominal view of mole crab (Albunea carabus L. 1758)

Mole crab determined in our study was male and has $20 \mathrm{~m}$ length and $2.8 \mathrm{~g}$ weight. Pereira et al. (2008) reported that carapace length was $11.31 \mathrm{~mm}$ and the weight was $2.20 \mathrm{~g}$ in male mole crabs which they caught by dredge. In the same study, it has been reported that the carapace size distribution varies between $3.3 \mathrm{~mm}$ and $25 \mathrm{~mm}$ in some of the subjects caught by some researchers.

The specimens determined in our study, have obtained from a sandy muddy deep between 10-20 m depth in off shore of Köprüçay. There is a limited number of studies on this species. These studies have reported that the mole ants prefer the sandy bottom (Pereira et al., 2008; Scuderi et al., 2017). Again, in the studies carried out on this species, the captured depth varied between 2-50 $\mathrm{m}$ (Pereira et al., 2008).

In this work, this species was obtained in front of Köprüçay River. Scuderi et al. (2017) reported that this species was intensively available in the mouths of freshwater on the coasts of Catania of Eastern Sicily. They have attributed this to the existence of numerous streams in the region and the fact that these rivers create cold flood waters and strong currents in winter.

As a result, Albunea carabus has been reported before in only the Gulf of Iskenderun of our country. This species has been reported for the first time from the Gulf of Antalya in our country

\section{Bibliografi}

Abdelsalam, K., Ramadan, S. E., 2017. First record of two crab species from the Egyptian Mediterranean Sea. Cahiers de Biologie Marine 58(1):17-23.

Boyko, C.B., 2002. A worldwide revision of the recent and fossil sand crabs of the Albuneidae Stimpson and Blepharipodidae, new family (crustacea: Decapoda: Anomura: Hippoidae) Bulletin of the American Museum of Natural History, 272: 1- 336.

Corsini, M., Kalogirou, S. 2013 First record of Albunea carabus (Linnaeus, 1758) (Decapoda: Anomura: Hippoidea) in the Aegean Sea. Cahiers de Biologie Marine 54: 297-299.

Giacobbe, S., Spanò, N., 1996. New Records of Albunea Carabus (L., 1758) (Decapoda, Anomura) in the Mediterranean Sea. Crustaceana 69 (6): 719-726.

Katağan, T. and Çevik, C. 2003. A new record of Albunea carabus (L., 1758) (Decapoda, Anomura, Hippidea) from the eastern Mediterranean coast of Turkey. Crustaceana. 76: 637-640.

Pereira, A.M, Rufino, M. M., Gaspar, M. B., 2008. First record of Albunea carabus (Decapoda, Anomura, Hippidea) from the Algarve coast, South Portugal. Marine Biology Research, Vol. 4 (3).

Scuderi, D., Villari., A., Angelico, M., 2017. A massive record of the rare 'mole crab' Albunea carabus (Decapoda: Anomura: Hippoidea) along the sandy coasts of Catania. Bulletin of the Entomological Society of Malta. Vol. 9, p. 43.

Spanò, N., Rinelli, P., Ragonese, S., 1998. The first find of Albunea carabus (Decapoda: Anomura) on the Southern Scilian Coasts (Strait of Sicily, Mediterranean Sea). Proceedings of the Fourth International Crustacean Congress 1998. 